\title{
Magnesium deficiency decreases biomass water-use efficiency and increases leaf water-use efficiency and oxidative stress in barley plants
}

\author{
Merle Tränkner • Bálint Jákli • Ershad Tavakol • \\ Christoph-Martin Geilfus • Ismail Cakmak • \\ Klaus Dittert • Mehmet Senbayram
}

Received: 5 November 2015 / Accepted: 4 April 2016/Published online: 17 April 2016

(C) The Author(s) 2016. This article is published with open access at Springerlink.com

\begin{abstract}
Aims In water-scarce agro-environments a clear understanding of how plant nutrients like magnesium $(\mathrm{Mg})$ affect plant traits related to water-use efficiency (WUE) is of great importance. Magnesium plays a crucial role in photosynthesis and is thus a major determinant of
\end{abstract}

Responsible Editor: Philip John White.

Electronic supplementary material The online version of this article (doi:10.1007/s11104-016-2886-1) contains supplementary material, which is available to authorized users.

M. Tränkner $(\bowtie) \cdot$ B. Jákli $\cdot$ E. Tavakol $\cdot$ K. Dittert

M. Senbayram

Institute of Applied Plant Nutrition, Carl-Sprengel-Weg 1,

Goettingen, Germany

e-mail: traenkner@iapn-goettingen.de

C.-M. Geilfus

Facility for Systems Biology based Mass Spectrometry, Division of Crop Biotechnics, KU Leuven, Willem de Croylaan 42, B-3001 Leuven, Belgium

\section{Cakmak}

Faculty of Engineering and Natural Sciences, Sabanci University, Istanbul, Turkey

M. Tränkner · B. Jákli · E. Tavakol · K. Dittert

Department of Crop Science, Section of Plant Nutrition \& Crop Physiology, University of Goettingen, Carl-Sprengel-Weg 1, Goettingen, Germany

Present Address:

M. Senbayram

Institute of Plant Nutrition and Soil Science, Faculty of

Agriculture, Harran University, SanliUrfa, Turkey biomass formation. This study investigated the effect of $\mathrm{Mg}$ deficiency on leaf and whole plant water-use efficiency, $\delta^{13} \mathrm{C}$ composition, hydrogen peroxide $\left(\mathrm{H}_{2} \mathrm{O}_{2}\right)$ production and the activity of key enzymes involved in ROS scavenging in barley.

Methods Barley (Hordeum vulgare) was grown in hydroponic culture under three different levels of $\mathrm{Mg}$ supply $(0.01,0.1,0.4 \mathrm{mM} \mathrm{Mg})$. WUE was determined on the leaf-level (leaf-WUE), the biomass-level (biomass-WUE) and via carbon isotope discrimination $\left(\delta^{13} \mathrm{C}\right)$. Additionally, concentrations of $\mathrm{Mg}$, chlorophyll and $\mathrm{H}_{2} \mathrm{O}_{2}$, and the activities of three antioxidative enzymes (ascorbate peroxidase, glutathione reductase and superoxide dismutase) in youngest fully expanded leaves were analyzed.

Results Dry matter production was significantly decreased (by $34 \%$ compared to control) in Mg deficient barley plants. Mg deficiency also markedly reduced leaf $\mathrm{Mg}$ concentrations and chlorophyll concentrations, but increased $\mathrm{H}_{2} \mathrm{O}_{2}$ concentrations (up to $55 \%$ compared to control) and the activity of antioxidative enzymes. Severe $\mathrm{Mg}$ deficiency decreased biomass-WUE by $20 \%$, which was not reflected regarding leaf-WUE. In line with leaf-WUE data, discrimination against ${ }^{13} \mathrm{C}$ (indicating time-integrated WUE) was significantly reduced under $\mathrm{Mg}$ deficiency.

Conclusions $\mathrm{Mg}$ deficiency increased oxidative stress indicating impairment in carbon gain and decreased biomass-WUE. Our study suggests that biomass-WUE was not primarily affected by photosynthesis-related processes, but might be dependent on effects of $\mathrm{Mg}$ on night-time transpiration, respiration or root exudation. 
Keywords Magnesium · Water use efficiency · Carbon discrimination · Oxidative stress $\cdot$ Barley

\section{Introduction}

The increasing world population and the concomitant decrease in water availability due to global climate change and land use change (Pachauri and Meyer 2014) raise an increasing challenge for higher agricultural crop productivity. A key factor limiting plant productivity under drought stress is water-use efficiency (WUE) of crop plants. In general, WUE describes the ratio of assimilated carbon to water used by the plant and is thus, a measure for the effciency in optimizing carbon assimilation while minimzing water use (Bramley et al. 2013). Usually, plants transpire much higher amounts of water compared to relatively small amounts of carbon that are fixed; between 200 and $1000 \mathrm{~g}$ of water are transpired per $\mathrm{g}$ of assimilated carbon (Bramley et al. 2013). Manipulating the ratio towards higher efficiency might contribute to the stabilization of yields under present and future conditions of diminishing fresh water supply and increasing food demand.

Water-use efficiency is a rather flexible term depending on the scale being considered, e.g. at the leaf or whole plant level. Biomass-WUE takes the whole plant into account and is defined as plant dry matter production per unit of water loss via transpiration during the vegetation period (Tallec et al. 2013). Biomass-WUE is affected by numerous factors related to biomass formation (e.g. photosynthesis, respiratory carbon loss) and whole plant transpiration (transpiration and unproductive water-loss by e.g. nocturnal transpiration) (Claussen 2002; Wang et al., 2013). Under field conditions, only aboveground biomass is considered for calculation of WUE (shoot-WUE), whereas in greenhouse experiments, where roots can be harvested, total biomass can be used for calculation of WUE (Bramley et al. 2013). Thus, biomass-WUE can be calculated as: Biomass-WUE = Total biomass (g)/Water use (L). Substantial variation in biomass-WUE under variable environmetal conditions (e.g. nutrient supply, water scarcity, elevated $\mathrm{CO}_{2}$ concentrations) have been reported (Cernusak et al. 2009; Lewis et al. 2011).

At the leaf level, intrinsic water-use efficiency (leafWUE) is defined as the instantaneous ratio between net $\mathrm{CO}_{2}$ assimilation rate (A) and stomatal conductance $\left(g_{s}\right)$ : Leaf-WUE $=\mathrm{A} / \mathrm{g}_{\mathrm{s}}$, whereas $\mathrm{g}_{\mathrm{s}}$ is the ratio of transpiration to air-to-leaf vapor pressure deficit. The carbon stable isotope composition of the plant dry matter $\left(\delta^{13} \mathrm{C}\right)$ is used as time-integrated indicator for WUE as it represents a measure of plant $C$ assimilation over the period during which dry matter is generated (Wang et al. 2013). Low carbon isotope discrimination $\left(\Delta^{13} \mathrm{C}\right)$ is seen as indicator of high leaf-WUE (Farquhar et al. 1982) and it has been commonly used as an indicator of leaf-WUE in wheat (Farquhar and Richards 1984), poplar (Rasheed et al. 2013) and tobacco (Brueck and Senbayram 2009). However, the relationship between $\Delta^{13} \mathrm{C}$ and leaf-WUE can be unbalanced by differences in the respective time of integration (Ripullone et al. 2004) or by variable mesophyll diffusion conductances $\left(\mathrm{g}_{\mathrm{m}}\right)$ (Warren and Adams 2006; Soolanayakanahally et al. 2009).

The different scales at which both types of WUE (at a leaf or whole plant level) are measured, might lead to discrepancies in upscaling leaf-WUE to biomass-WUE (Medrano et al. 2015) because components like canopy effects, night-time transpiration and respiration affect WUE differently. Night-time transpiration increases water use without concomitant carbon assimilation, thus lowering biomass-WUE. Medrano et al. (2015) reported that night-time transpiration accounted for $10 \%$ of the daily transpiration in grapevine. In addition, respiratory processes lead to carbon loss, thus reducing net carbon gain and also lowering biomass-WUE. Plant respiration plays a crucial role in carbon balance and might be a main unknown factor when comparing leaf-WUE and biomass-WUE (Medrano et al. 2015).

Water-use efficiency can be improved by plant breeding or different agronomical practices regarding soil and plant nutrient management (Blum 2009). Positive effects of adequate nitrogen (Shangguan et al. 2000; Brueck and Senbayram 2009) and potassium supply (Fournier et al. 2005; Arquero et al. 2006) on biomass-WUE and leafWUE were reported, but knowledge on how Mg deficiency may affect WUE in crop plants is scarce.

Magnesium as one of the essential plant nutrients, is the most abundant divalent cation in cellular systems $(\mathrm{Li}$ et al. 2001). Free $\mathrm{Mg}^{2+}$ ions stabilize membranes and are involved in activation of numerous enzymes, among them ATPases and ribulose-1,5-bisphosphate carboxylase/oxygenase (RubisCO) (Li et al. 2001; Shaul 2002). Magnesium is essential for chlorophyll synthesis and up to $10 \%$ of total $\mathrm{Mg}$ can be associated with chlorophyll (Wilkinson et al. 1990). Furthermore, $\mathrm{Mg}$ is important for grana stacking in chloroplasts (Hall et al. 1972; Ceppi et al. 2012) that may adversely affect photosynthetic performance of plants suffering from 
low Mg supply. It was reported that the degree of stacking increases with increasing $\mathrm{Mg}$ concentrations (Stys 1995) and Mg deficiency leads to disruption of grana stacks (Hall et al. 1972). Such involvements of $\mathrm{Mg}$ demonstrate its irreplaceable functions in photosynthesis. A reduction of dry matter production under $\mathrm{Mg}$ deficiency was observed in various plants, such as bean (Fischer and Bremer 1993; Cakmak et al. 1994a), sugar beet (Hermans et al. 2004), rice (Ding et al. 2006), Arabidopsis (Hermans and Verbruggen 2005). One of the earliest responses of plants to $\mathrm{Mg}$ deficiency is impaired phloem loading (Cakmak et al. 1994a). Photo-assimilates are not sufficiently transported from source leaves into sink tissues such as shoot tips, seeds and roots, leading to an accumulation of sucrose and starch in source leaves. This accumulation of carbohydrates commonly occurs before visible $\mathrm{Mg}$ deficiency symptoms develop, e.g. interveinal chlorosis and necrotic lesions on leaves and reduction in shoot biomass and also before any distinct change in photosynthetic performance of plants is detectable (Cakmak and Kirkby 2008; Verbruggen and Hermans 2013). The sucrose accumulation may trigger a downregulation of genes involved in photosynthesis (Jang and Sheen 1994) or a carbon-metabolite feedback inhibition of photosynthesis, whereas both processes inevitably decrease assimilation. A decrease in assimilation is also caused by reduced acitivities of enzymes involved in $\mathrm{CO}_{2}$ fixation (Cakmak and Kirkby 2008). Decreased capacity to fix $\mathrm{CO}_{2}$ leads to an overreduction of the photosynthetic electron transport chain, initiating the photoreduction of dioxygen $\left(\mathrm{O}_{2}\right)$ to superoxide $\left(\mathrm{O}_{2}{ }^{-}\right)$and subsequently the catalysis of superoxide to $\mathrm{H}_{2} \mathrm{O}_{2}$ by superoxide dismutase (Asada 1999). $\mathrm{H}_{2} \mathrm{O}_{2}$ is suggested to act as a signal messenger (Møller et al. 2007), being involved in abiotic and biotic stress response (Cheeseman 2007). However, increased levels of $\mathrm{H}_{2} \mathrm{O}_{2}$ cause oxidative damage to cell components (Foyer and Noctor 2011). Additionally, the presence of $\mathrm{H}_{2} \mathrm{O}_{2}$ inhibits the activity of enzymes involved in photosynthesis, in particular RubisCO (Asada 1999), further limiting the photonutilization capacity and ultimately enhancing the production of reactive oxygen species. Enhanced $\mathrm{H}_{2} \mathrm{O}_{2}$ generation is also typical under low water supply, contributing to ABA-induced stomatal closure ( $\mathrm{Hu}$ et al. 2006; Wang and Song 2008), lipid peroxidation and chlorophyll degradation (Farooq et al. 2009; Foyer and Shigeoka 2011). Under such conditions, detoxification of $\mathrm{H}_{2} \mathrm{O}_{2}$ is extremely important and it is achieved by ascorbate peroxidase (APX) in the chloroplast (Foyer and Noctor 2011). APX reduces $\mathrm{H}_{2} \mathrm{O}_{2}$ to $\mathrm{H}_{2} \mathrm{O}$ at the expense of ascorbate which is subsequently regenerated either by oxidation of monohydroascorbate or by reduction of dehydroascorbate. For the latter, glutathione serves as the reductant wich is generated from reducing glutathione sulfide by glutathione reductase (GR) (Polle 2001). Enhanced activities of the antioxidant enzymes indicate photooxidative stress as commonly observed under Mg deficiency (Cakmak and Kirkby 2008). An up-regulation of antioxidant enzyme activities and antioxidant metabolites was observed in common bean (Cakmak and Marschner 1992), citrus (Tang et al. 2012), wheat (Mengutay et al. 2013) and maize (Tewari et al. 2006).

In the future, incidences and duration of drought are predicted to increase, posing a risk to agricultural production and yield stability. Plants suffering Mg deficiency are assumed to be more sensitive to drought and adequate $\mathrm{Mg}$ supply is needed for optimal yield formation under drought situations (Senbayram et al. 2015a). Hence, a clear understanding of how $\mathrm{Mg}$ affects plant traits related to water-use efficiency (WUE) is of great importance. To our knowledge, there are no published reports on effects of Mg-deficiency on leaf- and biomass-WUE. For several reasons, WUE of plants can be adversely affected by the $\mathrm{Mg}$ nutritional status of plants. For example, it is well known that an adequate $\mathrm{Mg}$ nutrition is required for stomatal conductance of plants (Laing et al. 2000; Cakmak and Kirkby 2008). In addition, welldocumented reductions in root growth due to impairments in carbon partitioning into roots (Cakmak et al. 1994a; Hermans et al. 2004) may greatly affect root water uptake from growth medium as suggested by Cakmak and Kirkby, (2008) and Senbayram et al. (2015a, b). This study has been conducted to increase knowledge regarding direct effect of varying $\mathrm{Mg}$ supply on biomass-WUE and related parameters, including carbon assimilation, carbon isotope discrimination and ascorbate peroxidase activity in combination with the capacity to form $\mathrm{H}_{2} \mathrm{O}_{2}$ under non-limiting water supply.

\section{Materials and methods}

Plant culture

Seeds of Hordeum vulgare L cv. Şahin-91 were germinated in wetted paper rolls in the greenhouse and 
seedlings were transferred to hydroponic plant culture using 51 pots ( 2 plants per pot). In order to avoid osmotic shock, seedlings were grown in half-strength nutrient solution for the first 5 days, then transferred to $75 \%$ of full-strength nutrient solution for another 6 days before supplying full-strength nutrient solution. Fullstrength nutrient solution contained $2 \mathrm{mM} \mathrm{K}_{2} \mathrm{SO}_{4}$, $3 \mathrm{mM} \mathrm{NH}_{4} \mathrm{NO}_{3}, 1 \mathrm{mM} \mathrm{MgSO}_{4} * 7 \mathrm{H}_{2} \mathrm{O}, 1 \mathrm{mM} \mathrm{CaCl}_{2} * 2$ $\mathrm{H}_{2} \mathrm{O}, 0.25 \mathrm{mM} \mathrm{Ca}\left(\mathrm{H}_{2} \mathrm{PO}_{4}\right)_{2} * \mathrm{H}_{2} \mathrm{O}, 0.1 \mathrm{mM}$ Fe-EDTA, $25 \mu \mathrm{M} \mathrm{H} \mathrm{BO}_{3}, 2 \mu \mathrm{M} \mathrm{ZnSO}{ }_{4} * 7 \mathrm{H}_{2} \mathrm{O}, 2 \mu \mathrm{M}$ $\mathrm{MnSO}_{4} * \mathrm{H}_{2} \mathrm{O}, 0.5 \mu \mathrm{M} \mathrm{CuSO}{ }_{4} * 5 \mathrm{H}_{2} \mathrm{O}, 0.075 \mu \mathrm{M}$ $\mathrm{H}_{24} \mathrm{Mo}_{7} \mathrm{~N}_{6} \mathrm{O}_{24} * 4 \mathrm{H}_{2} \mathrm{O} .24$ days after germination, three magnesium levels were introduced: $0.01 \mathrm{mM}\left(\mathrm{Mg}_{\text {low }}\right)$, $0.1 \mathrm{mM}\left(\mathrm{Mg}_{\mathrm{med}}\right)$ and $0.4 \mathrm{mM} \mathrm{MgSO}_{4} * 7 \mathrm{H}_{2} \mathrm{O}\left(\mathrm{Mg}_{\text {high }}\right)$. In order to avoid nutrient depletion, nutrient solutions were renewed every 5 days at the beginning of the experiment and every 2 days at later growth stages. Nutrient solutions were permanently aerated.

Determination of $\mathrm{Mg}$ concentrations, SPAD and $\delta^{13} \mathrm{C}$

Plants were harvested 34 days after onset of treatments (DAO), separated into roots and shoots and dried at $60{ }^{\circ} \mathrm{C}$ for dry matter (DM) determination. In order to assess chlorophyll concentrations, SPAD readings (Konica Minolta, Japan) were taken on youngest fully expanded leaves. For determination of magnesium concentration, $100 \mathrm{mg}$ of dried plant material was digested in $4 \mathrm{ml}$ concentrated $\mathrm{HNO}_{3}$ and $2 \mathrm{ml} 30 \% \mathrm{H}_{2} \mathrm{O}_{2}$ at $200{ }^{\circ} \mathrm{C}$ and 15 bar for $75 \mathrm{~min}$. Magnesium concentrations were measured by ICP-OES (Vista RL, CCD simultaneous ICP-OES, Varian Inc., USA) and atomic absorption spectrometry (220 FS, Varian Inc., USA).

The carbon isotope discrimination $\left(\Delta^{13} \mathrm{C}\right)$ was analyzed as a measure of time-integrated leaf-WUE. The ratio of ${ }^{13} \mathrm{C}$ to ${ }^{12} \mathrm{C}$ in shoot dry matter and in young leaves was determined after Dumas combustion on a ThermoFinnigan Delta Plus IRMS (ThermoFinnigan, Bremen, Germany). $\delta^{13} \mathrm{C}$ was calculated by relating the measured isotopic ratio to Vienna PeeDee Belemnite lime stone formation (VPDB) (according to Smith and Epstein 1971). For analyzing the relationship between leaf-WUE and leaf $\delta^{13} \mathrm{C}$ values, mean leaf-WUE was calculated via temporal integration. For analyzing the relationship between total biomass-WUE and leaf $\delta^{13} \mathrm{C}$ values, two additional replications of $\mathrm{Mg}_{\text {low }}$ and $\mathrm{Mg}_{\text {high }}$ were included in the dataset. These two additional replications were harvested on 20 DAO and total biomassWUE was determined as described below.
Determination of hydrogen peroxide concentrations and ascorbate peroxidase activity

Determination of $\mathrm{H}_{2} \mathrm{O}_{2}$ concentration was conducted using ferrous ammonium sulfate xylenol orange (FOX) solution described by Wolff (1994) and modified by Cheeseman (2009). Briefly, 3 leaf discs were taken from young leaves using a cork borer $\left(0.46 \mathrm{~cm}^{2}\right)$ and were transferred to $1 \mathrm{ml}$ acetone acidified by adding $25 \mathrm{mM} \mathrm{H}_{2} \mathrm{SO}_{4}$. Samples were frozen in liquid nitrogen. For measurements, FOX solution containing $250 \mu \mathrm{M}$ ferrous ammonium sulfate, $100 \mathrm{mM}$ sorbitol, $100 \mu \mathrm{M}$ xylenol orange and $25 \mathrm{mM} \mathrm{H}_{2} \mathrm{SO}_{4}$ was prepared prior to thawing the samples at room temperature for $45 \mathrm{~min}$. $1 \mathrm{ml}$ of FOX solution was added to $50 \mu \mathrm{l}$ of each sample which were previously dissolved in acidified acetone. Samples were incubated at room temperature for 30 45 min. $\mathrm{H}_{2} \mathrm{O}_{2}$ was quantified spectrometrically (EPOCH, BioTec, USA/8453 UV-VIS Spectroscopy System, Agilent, USA) at $550 \mathrm{~nm}$ and subtracting the background at $850 \mathrm{~nm}$ using a standard curve ranging from 0 to $100 \mu \mathrm{M}$.

For measurement of ROS scavenging enzyme activities, leaf samples were harvested and immediately frozen in liquid nitrogen. $0.5 \mathrm{~g}$ of samples were homogenized in $5 \mathrm{ml}$ phosphate buffer (pH 7.6) including $1 \%$ polyvinylpyrrolidone (PVP) and $0.1 \mathrm{mM}$ EDTA and centrifuged for $20 \mathrm{~min}$ at $16,000 \mathrm{~g}$ at $4{ }^{\circ} \mathrm{C}$. The supernatant was collected and used as crude extract in the reaction mixtures of the enzyme activity assays.

For ascorbate peroxidase (APX) assay, the $0.3 \mathrm{ml}$ reaction mixture contained $0.5 \mathrm{mM}$ ascorbic acid, $50 \mathrm{mM}$ phosphate buffer, $1 \mathrm{mM}$ EDTA, $0.5 \mathrm{mM} \mathrm{H}_{2} \mathrm{O}$ and $10-15 \mu \mathrm{l}$ of the supernatant. The reaction was started by adding $10 \mu \mathrm{l}$ of $15 \mathrm{mM}$ of $\mathrm{H}_{2} \mathrm{O}_{2}$ and APX was assayed spectrometrically (EPOCH, BioTec, USA/ 8453 UV-VIS Spectroscopy System, Agilent, USA) following the decrease of absorbance at $290 \mathrm{~nm}$ (Nakano and Asada 1981).

Glutathione reductase (GR) was assayed according to Halliwell and Foyer (1978) with slight modifications. The $0.3 \mathrm{ml}$ reaction mixture contained $0.2 \mathrm{mM}$ nicotinamide adenine dinucleotide phosphate (NADPH), 1 mM GSSG (glutathione disulfide; oxidized form of glutathione), $50 \mathrm{mM} \mathrm{K-P}$ buffer (pH 7.6) with $0.1 \mathrm{mM}$ EDTA and $10-15 \mu$ of crude extract. GR was determined following the decrease in absorbance at $340 \mathrm{~nm}$ as NADPH was oxidized. 
The background was corrected by observing the nonenzymatic oxidation of NADPH in the absence of GSSG. Superoxide dismutase (SOD) activity was determined according to Giannopolitis and Ries (1977) with small modifications. The $0.3 \mathrm{ml}$ reaction mixture contained $50 \mathrm{mM}$ phosphate buffer, $0.1 \mathrm{mM}$ EDTA, $50 \mathrm{mM} \mathrm{Na} \mathrm{CO}_{3}, 12 \mathrm{mM}$ L-methionine, $75 \mu \mathrm{M}$ nitroblue tetrazolium (NBT), $2 \mu \mathrm{M}$ riboflavin and $10-20 \mu \mathrm{l}$ of the enzyme extract. Riboflavin was added at last and the samples were placed under fluorescent light (4000 lx) for $10 \mathrm{~min}$. Following that, the inhibition of photoreduction of NBT by SOD was measured at $560 \mathrm{~nm}$. Blank samples with no crude extract where considered having the highest reaction rate of super oxide with NBT. One unit of SOD activity is defined as the amount of enzyme required to cause $50 \%$ inhibition of the rate of NBT reduction at $560 \mathrm{~nm}$.

Gas exchange measurements and calculation of leaf water-use efficiency

Net assimilation and stomatal conductance were determined on youngest fully expanded leaves (GFS-3000, Heinz Walz GmbH, Germany). Cuvette conditions were set as follows: $22^{\circ} \mathrm{C}, 55 \%$ rel. humidity, $380 \mathrm{ppm} \mathrm{CO}_{2}$, photosynthetic photon flux density of $1000 \mu \mathrm{mol} \mathrm{m} \mathrm{m}^{-2} \mathrm{~s}^{-1}$ generated by blue and red LEDs. After reaching stable values due to leaf adjustment to cuvette conditions (after 30 to $45 \mathrm{~min}$.), fluxes were averaged over $5 \mathrm{~min}$. Leaf water-use efficiency (leafWUE) was determined by relating net assimilation to stomatal conductance.

Calculation of transpiration and biomass water-use efficiency

Daily whole plant transpiration was assessed by measuring daily weight differences of the pots. Each pot was placed on a balance (TQ30, ATP Messtechnik, Germany), automatically recording the weight in an interval of $30 \mathrm{~min}$. in a one-gram-resolution. As pots were sealed, weight reduction of pots was solely caused by transpiration of plants. Cumulative transpiration was calculated by summing up daily weight differences. Shoot biomass water-use efficiency (shoot biomass-WUE) was determined by relating the shoot dry mass to the cumulative transpiration and total biomass water-use efficiency (total biomass-WUE) was determined by relating the total plant dry mass to the cumulative transpiration.

Modelling plant growth and daily shoot water-use efficiency

To allow comparison of daily shoot-WUE an empirical model procedure was developed to estimate daily biomass production from leaf area (LA) development. For this purpose, 30 pots of barley plants were grown in a preliminary trial under conditions similar to those of the main experiment. Plant images were taken from a fixed position (defined distance and angle) at least twice a week in front of a black background using a digital single-lens reflex camera (Canon EOS 600D, Canon Inc., Japan). The area of green pixels in each picture was calculated using ImageJ software (Rasband 1997). After the imaging procedure, plants of two pots were harvested and total leaf area per pot was determined using a desktop scanner together with ImageJ. Measured LA of the harvested pots was plotted against the respective area of green pixels and a second order polynomial was fitted (see Online Resource 1). The parameters of the polynomial were used for calculating LA per pot from plant images only. The linear regression between observed and predicted LA together with the mean absolute predictive discrepancy (MD) were used to indicate the goodness of fit $\left(\mathrm{r}^{2}=0.98, p<0.001\right.$, $\mathrm{MD}=87.1 \mathrm{~cm}^{2}$ ). During the main experiment, LA was imaged at least once a week. To obtain daily values of LA development, three-parametric logistic growth curves of the shape $f(x)=\frac{a}{1+b e^{(-k t)}}$ (where a, b, k are the estimated parameters of the function and $\mathrm{t}$ is temporal component) were calculated from iterative non-linear least-square regression using the $n l s$-function implemented in R (R Core Team 2014). Daily shoot dry matter was estimated assuming that growth curves of shoot dry matter production follow the same curve progression as leaf area production.

The logistic curves obtained from the imaging of leaf area development were fitted to three discrete data points along the experimental period where DM per pot was known (start of experiment, second harvest) or could be estimated (first harvest). Parameters a and $b$ were re-fitted, k was considered constant. For estimating dry matter at the first harvest date, the ratio of LA to shoot DM was calculated from plants harvested on that day. Mean ratio per treatment was then used to calculate 
shoot DM for each pot not harvested on that day with respect to treatments. The resulting curves of total daily dry matter per pot were differentiated to obtain values of dry matter production per day and pot (daily DM) (see Online Resource 2).

Daily shoot-WUE was calculated by relating daily DM increase to daily whole plant transpiration.

\section{Statistical analyses}

Statistical analyses were performed using $\mathrm{R}$ version 3.0.3 (R Core Team 2014). Analysis of variance (ANOVA) was performed to determine whether effects of treatments on the respective factor were significant, followed by Duncan's post-hoc test $(\alpha=0.05)$ where ANOVA indicated significance. Data were tested for normal distribution with Shapiro-Wilk-Test and, where necessary, transformed logarithmically. Data are displayed untransformed.

\section{Results}

Plant dry matter formation, $\mathrm{Mg}$ leaf concentrations and chlorophyll content

At the final harvest, 34 days after onset of treatments (DAO), plant total dry matter (DM), shoot DM and root DM decreased significantly with decreasing rate of $\mathrm{Mg}$ supply (Table 1). Total DM was about $73 \%$ and $34 \%$ lower in plants supplied with $0.01 \mathrm{mM} \mathrm{Mg}\left(\mathrm{Mg}_{\text {low }}\right)$ and $0.1 \mathrm{mM} \mathrm{Mg}\left(\mathrm{Mg}_{\mathrm{med}}\right)$ as compared to plants treated with $0.4 \mathrm{mM} \mathrm{Mg}\left(\mathrm{Mg}_{\text {high }}\right)$. The shoot/root ratio was unaffected by the rate of $\mathrm{Mg}$ supply (Table 1). Over all treatments, total DM production correlated well with shoot Mg uptake $\left(r^{2}=0.923\right)$ (Fig. 1) and leaf $\mathrm{Mg}$ concentrations were significantly lower in $\mathrm{Mg}_{\text {low }}$ and $\mathrm{Mg}_{\text {med }}$ when compared to $\mathrm{Mg}_{\text {high }}$ treated plants. This effect was more severe in older leaves than in younger leaves (Table 1). Highest Mg concentrations were measured in youngest fully expanded leaves in $\mathrm{Mg}_{\text {high }}$ treatment $\left(1.09 \pm 0.07 \mathrm{mg} \mathrm{g}^{-1} \mathrm{DM}\right) . \mathrm{Mg}$ concentrations in leaves of medium and low $\mathrm{Mg}$ supplied plants were $37 \%$ and $62 \%$ lower than in plants treated with $\mathrm{Mg}_{\text {high }}$ $34 \mathrm{DAO}$, respectively. However, in older leaves, $\mathrm{Mg}$ concentrations in $\mathrm{Mg}_{\text {low }}\left(0.25 \pm 0.01 \mathrm{mg} \mathrm{g}^{-1} \mathrm{DM}\right)$ and $\mathrm{Mg}_{\text {med }}\left(0.45 \pm 0.08 \mathrm{mg} \mathrm{g}^{-1} \mathrm{DM}\right)$ treated plants were $74 \%$ and $53 \%$ lower compared to plants supplied with $\mathrm{Mg}_{\text {high. }}$ Leaf SPAD values that were recorded to assess leaf chlorophyll content were similar in all treatments until 9 DAO. Then, until 33 DAO, SPAD readings decreased steadily to $64 \%$ and $57 \%$ in $\mathrm{Mg}_{\text {low }}$ and $\mathrm{Mg}_{\text {med }}$, but remained almost constant in $\mathrm{Mg}_{\text {high }}$ (Fig. 2).

Hydrogen peroxide concentration and ROS scavenging enzyme activity

Hydrogen peroxide concentrations in youngest fully expanded leaves of $\mathrm{Mg}_{\text {low }}$ plants were $40 \%$ and $55 \%$ higher than in $\mathrm{Mg}_{\text {high }}$ on $13 \mathrm{DAO}$ and $33 \mathrm{DAO}$ (Fig. 3a). Overall, the activities of ROS scavenging enzymes were higher in $\mathrm{Mg}$ deficient plants. $13 \mathrm{DAO}$, the activities of APX and GR were 4- and 3-fold higher in $\mathrm{Mg}_{\text {low }}$ than in $\mathrm{Mg}_{\text {high, }}$ and $33 \mathrm{DAO}$, they were 5- and 3-fold higher (Fig. 3b, c). Superoxide dismutase, the enzyme being responsible for the reduction of superoxide to hydrogen peroxide, showed highest activity in $\mathrm{Mg}$ deficient plants. In contrast to APX and GR, the SOD activity of $\mathrm{Mg}_{\text {low }}$ and $\mathrm{Mg}_{\text {med }}$ treatments did not differ from each other (Fig. 3d).
Table 1 Effect of Mg supply on total DM (g per pot), shoot DM (g per pot), root DM (g per pot), shoot-to-root ratio, $\mathrm{Mg}$ concentration (young and old leaves; $\mathrm{mg} \mathrm{g}^{-1} \mathrm{DM}$ ), $\delta^{13} \mathrm{C}$, total biomass water-use efficiency (biomass-WUE, $\mathrm{g} \mathrm{L}^{-1}$ ) and shoot-WUE $\left(\mathrm{g} \mathrm{L}^{-1}\right)$ in low $\mathrm{Mg}(0.01 \mathrm{mM} \mathrm{Mg})$, medium $\mathrm{Mg}(0.1 \mathrm{mM} \mathrm{Mg})$, and high $\mathrm{Mg}(0.4 \mathrm{mM} \mathrm{Mg})$ treated barley plants. Values are means \pm SE $(n=3)$. Means followed by the same small letter are not significantly different $(\alpha=0.05)$

\begin{tabular}{|c|c|c|c|c|c|c|c|c|}
\hline \multirow{2}{*}{$\begin{array}{l}\text { Mg supply } \\
(\mathrm{mM})\end{array}$} & \multicolumn{3}{|l|}{ Dry matter } & \multirow{2}{*}{$\begin{array}{l}\text { Shoot/root } \\
\text { ratio }\end{array}$} & \multicolumn{2}{|c|}{ Mg concentration } & \multicolumn{2}{|l|}{ Biomass-WUE } \\
\hline & total $(\mathrm{g})$ & shoot $(\mathrm{g})$ & $\operatorname{root}(\mathrm{g})$ & & $\begin{array}{l}\text { young leaf } \\
\left(\mathrm{mg} \mathrm{g}^{-1} \mathrm{DM}\right)\end{array}$ & $\begin{array}{l}\text { old leaf } \\
\left(\mathrm{mg} \mathrm{g}^{-1} \mathrm{DM}\right)\end{array}$ & total $\left(\mathrm{g} \mathrm{DM} \mathrm{L}^{-1}\right)$ & $\begin{array}{l}\text { shoot } \\
\left(\mathrm{g} \mathrm{DM} \mathrm{L}{ }^{-1}\right)\end{array}$ \\
\hline 0.01 & $17.9 \pm 1.38 \mathrm{c}$ & $15.56 \pm 1.22 \mathrm{c}$ & $2.38 \pm 0.15 \mathrm{c}$ & $6.53 \pm 0.11 \mathrm{a}$ & $0.41 \pm 0.00 \mathrm{c}$ & $0.25 \pm 0.01 \mathrm{~b}$ & $3.77 \pm 0.12 b$ & $3.27 \pm 0.10 \mathrm{~b}$ \\
\hline 0.1 & $38.8 \pm 1.63 \mathrm{~b}$ & $33.36 \pm 1.21 \mathrm{~b}$ & $5.42 \pm 0.43 b$ & $6.20 \pm 0.29 a$ & $0.69 \pm 0.06 \mathrm{~b}$ & $0.45 \pm 0.08 \mathrm{~b}$ & $4.49 \pm 0.28 \mathrm{a}$ & $3.86 \pm 0.22 \mathrm{a}$ \\
\hline 0.4 & $53.2 \pm 0.50 \mathrm{a}$ & $46.06 \pm 0.59 \mathrm{a}$ & $7.08 \pm 0.50$ & $6.58 \pm 0.54 \mathrm{a}$ & $1.09 \pm 0.07 \mathrm{a}$ & $0.96 \pm 0.14 \mathrm{a}$ & $4.55 \pm 0.13 \mathrm{a}$ & $3.95 \pm 0.14 \mathrm{a}$ \\
\hline
\end{tabular}




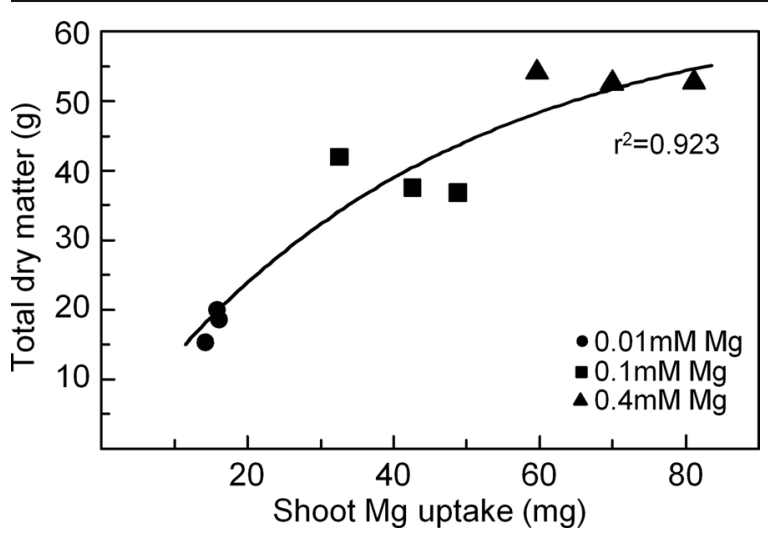

Fig. 1 Relationship between total DM (g per pot) and shoot $\mathrm{Mg}$ uptake in low $\mathrm{Mg}(0.01 \mathrm{mM} \mathrm{Mg})$, medium $\mathrm{Mg}(0.1 \mathrm{mM} \mathrm{Mg})$, and high $\mathrm{Mg}(0.4 \mathrm{mM} \mathrm{Mg})$ treatments of barley plants

\section{Leaf water-use efficiency}

Temporal courses of net assimilation rate $\left(\mathrm{A}_{\mathrm{N}}\right)$ and stomatal conductance $\left(\mathrm{g}_{\mathrm{s}}\right)$ measured on youngest fully expanded leaves are presented in Fig. 4. In treatments $\mathrm{Mg}_{\text {high }}$ and $\mathrm{Mg}_{\text {med }}$, mean $\mathrm{A}_{\mathrm{N}}$ were $26.8 \pm 0.64$ and $21.2 \pm 0.27 \mu \mathrm{mol} \mathrm{CO} \mathrm{CO}^{-2} \mathrm{~s}^{-1}$, and remained almost constant throughout the experimental period. However in $\mathrm{Mg}_{\text {low }}, \mathrm{A}_{\mathrm{N}}$ decreased rapidly and already starting 8 $\mathrm{DAO}$, it was significantly lower than in the other $\mathrm{Mg}$ treatments. Here, $\mathrm{A}_{\mathrm{N}}$ was $11.7 \pm 1.14 \mu \mathrm{mol} \mathrm{m}^{-2} \mathrm{~s}^{-1}$ in $\mathrm{Mg}_{\text {low }}$, being $59 \%$ lower than in $\mathrm{Mg}_{\text {high }}$. Stomatal conductance $\left(\mathrm{g}_{\mathrm{s}}\right)$ decreased in all three $\mathrm{Mg}$-supply treatments during the experimental period. However, the

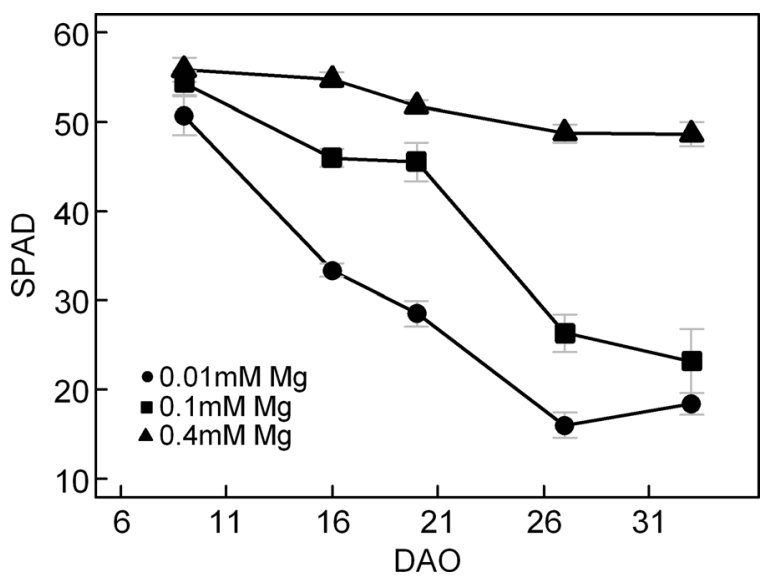

Fig. 2 SPAD values measured on old leaves in low $\mathrm{Mg}$ $(0.01 \mathrm{mM} \mathrm{Mg})$, medium $\mathrm{Mg}(0.1 \mathrm{mM} \mathrm{Mg})$, and high $\mathrm{Mg}$ $(0.4 \mathrm{mM} \mathrm{Mg})$ treatments of barley plants. Means $\pm \mathrm{SE}(n=3)$. $\mathrm{DAO}=$ days after onset of treatment

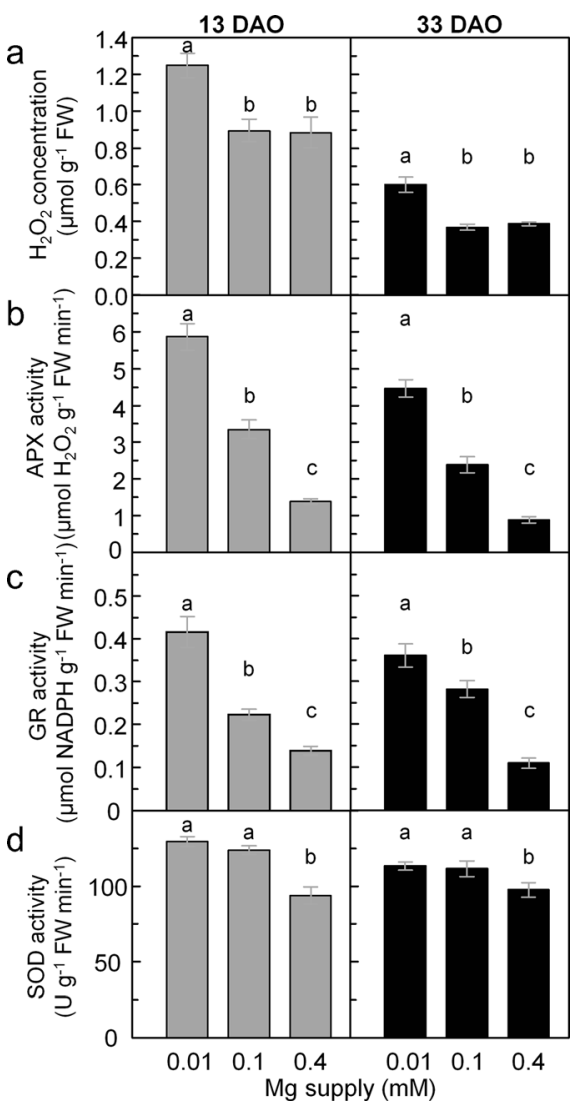

Fig. 3 Hydrogen peroxide $\left(\mathrm{H}_{2} \mathrm{O}_{2}\right)$ concentrations (a), ascorbate peroxidase (APX) activity (b), glutathione reductase (GR) activity (c), and superoxide dismutase (SOD) activity (d) in low $\mathrm{Mg}$ (0.01 $\mathrm{mM} \mathrm{Mg})$, medium $\mathrm{Mg}(0.1 \mathrm{mM} \mathrm{Mg})$, and high $\mathrm{Mg}$ $(0.4 \mathrm{mM} \mathrm{Mg})$ treatments of barley plants at 13 and 33 days after onset of treatment (DAO). Error bars represent standard errors ( $n=6, n=12$ for hydrogen peroxide). Means labelled with the same small letter are not significantly different $(\alpha=0.05)$

decrease in $\mathrm{g}_{\mathrm{s}}$ was more pronounced in $\mathrm{Mg}_{\text {low. }}$. From 6 to $13 \mathrm{DAO}$ in $\mathrm{Mg}_{\text {low }}$, the $\mathrm{g}_{\mathrm{s}}$ values decreased from $267.5 \pm 19.6 \mathrm{mmol} \mathrm{m}^{-2} \mathrm{~s}^{-1} \mathrm{to}$ $125.8 \pm 24.9 \mathrm{mmol} \mathrm{m}^{-2} \mathrm{~s}^{-1}$ and remained almost constant thereafter. Interestingly, the decrease in $g_{s}$ was more pronounced than the decrease in $\mathrm{A}_{\mathrm{N}}$ and thus, affected the leaf-WUE $\left(\mathrm{A}_{\mathrm{N}} / \mathrm{g}_{\mathrm{s}}\right)$ significantly. In $\mathrm{Mg}_{\text {low }}$, leaf-WUE was $79.29 \pm 3.87 \mu \mathrm{mol} \mathrm{CO} \mathrm{mol}^{-1} \mathrm{H}_{2} \mathrm{O}$ at $6 \mathrm{DAO}$, being already slightly higher than in $\mathrm{Mg}_{\text {high }}$, and over time, it increased to $92.51 \pm 3.94 \mu \mathrm{mol} \mathrm{CO} \mathrm{mol}^{-1} \mathrm{H}_{2} \mathrm{O}$ on 33 DAO. In $\mathrm{Mg}_{\text {high }}$, leaf-WUE was $56.38 \pm 2.67 \mu \mathrm{mol} \mathrm{CO}$ $\mathrm{mol}^{-1} \mathrm{H}_{2} \mathrm{O}$ on $8 \mathrm{DAO}$ and increased gradually to $88.8 \pm 10.44 \mu \mathrm{mol} \mathrm{CO} \mathrm{mol}^{-1} \mathrm{H}_{2} \mathrm{O}$ until $33 \mathrm{DAO}$ (Fig. 4c). In $\mathrm{Mg}_{\text {med }}$, leaf-WUE remained almost constant during the experiment, being similar to leaf-WUE in $\mathrm{Mg}_{\text {high }}$, except for the measurement on 13 DAO. 


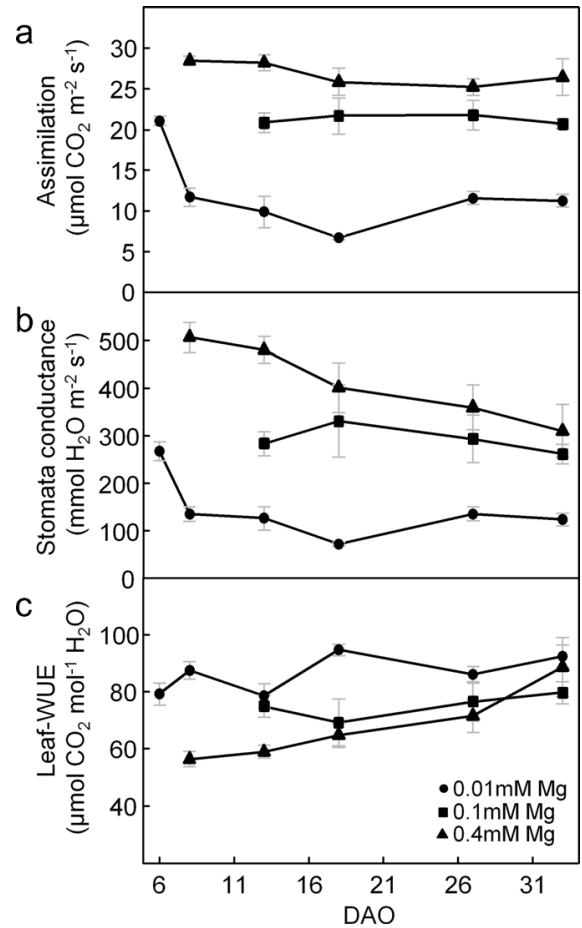

Fig. 4 Net assimilation (a), stomatal conductance (b) and leaf water-use efficiency (leaf-WUE) (c) in low $\mathrm{Mg}(0.01 \mathrm{mM} \mathrm{Mg})$, medium $\mathrm{Mg}(0.1 \mathrm{mM} \mathrm{Mg})$, and high $\mathrm{Mg}(0.4 \mathrm{mM} \mathrm{Mg})$ treatments of barley plants. Symbols represent means $\pm \operatorname{SE}(n=3)$. $\mathrm{DAO}=$ days after onset of treatment

\section{Biomass water-use efficiency}

Overall, total biomass-WUE of barley plants ranged from 3.77 to $4.55 \mathrm{~g} \mathrm{DM} \mathrm{L}^{-1} \mathrm{H}_{2} \mathrm{O}$ on $34 \mathrm{DAO}$ (Table 1). Here was no significant difference when comparing $\mathrm{Mg}_{\text {high }}$ and $\mathrm{Mg}_{\text {med }}$, however, total biomassWUE in $\mathrm{Mg}_{\text {low }}$ was significantly lower (17\% lower total biomass-WUE) than in both $\mathrm{Mg}_{\text {high }}$ and $\mathrm{Mg}_{\text {med }}$ (Table 1). The effect of Mg supply on shoot biomassWUE followed the same trend as with total biomassWUE (Table 1).

Daily shoot water-use efficiency

Daily shoot-WUE (DM production day ${ }^{-1} /$ transpiration day ${ }^{-1} \operatorname{pot}^{-1}$ ) was calculated by estimating the biomass production and relating it to the measured daily transpiration. The daily shoot-WUE of all three treatments increased from treatment start and showed quite simultaneous maxima at day 18 and 19 (Fig. 5). These maximum daily shoot-WUE of $\mathrm{Mg}_{\text {high }}, \mathrm{Mg}_{\text {med }}$ and $\mathrm{Mg}_{\text {low }}$ were 4.9, 5.8 and $5.6 \mathrm{~g} \mathrm{DM} \mathrm{L}^{-1} \mathrm{H}_{2} \mathrm{O}$. Subsequently, the daily shoot-WUE decreased until 32 DAO in all three treatments, however, the decline was much more pronounced in $\mathrm{Mg}_{\text {low }}$. Here, daily shoot-WUE declined by $75 \%$ to $1.4 \mathrm{~g} \mathrm{DM} \mathrm{L}^{-1} \mathrm{H}_{2} \mathrm{O}$ at $32 \mathrm{DAO}$, thus having a daily shoot-WUE of only $44 \%$ compared to the control.

\section{Carbon isotope composition}

The $\delta^{13} \mathrm{C}$ values of the shoot biomass decreased with increasing Mg supply (Fig. 6a). Highest discrimination was observed in control plants and plants with medium Mg supply ( $-30.47 \pm 0.37 \%$ and $-29.26 \pm 0.37 \%$ ). In $\mathrm{Mg}$ deficient plants, $\delta^{13} \mathrm{C}$ values were significantly higher $(-27.66 \pm 0.14 \%)$ compared to the control. $\delta^{13} \mathrm{C}$ values of young leaves showed significant positive correlation with integrated leaf-WUE (Fig. 6b). However, there was no common relationship between shoot $\delta^{13} \mathrm{C}$ values and total biomass-WUE (Fig. 6c), but
Fig. 5 Daily shoot water-use efficiency in low $\mathrm{Mg}$ (0.01 $\mathrm{mM} \mathrm{Mg})$, medium $\mathrm{Mg}$ $(0.1 \mathrm{mM} \mathrm{Mg})$, and high $\mathrm{Mg}$ $(0.4 \mathrm{mM} \mathrm{Mg})$ treatments of barley plants. Represented are means $\pm \mathrm{SE}(n=3)$. Error bars represent standard errors. DAO = days after onset of treatment

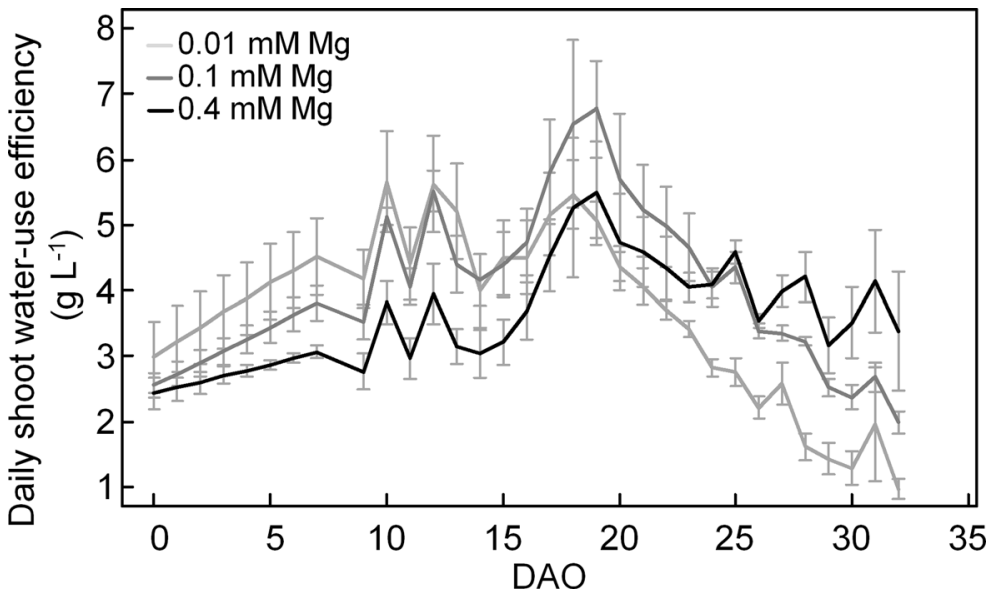



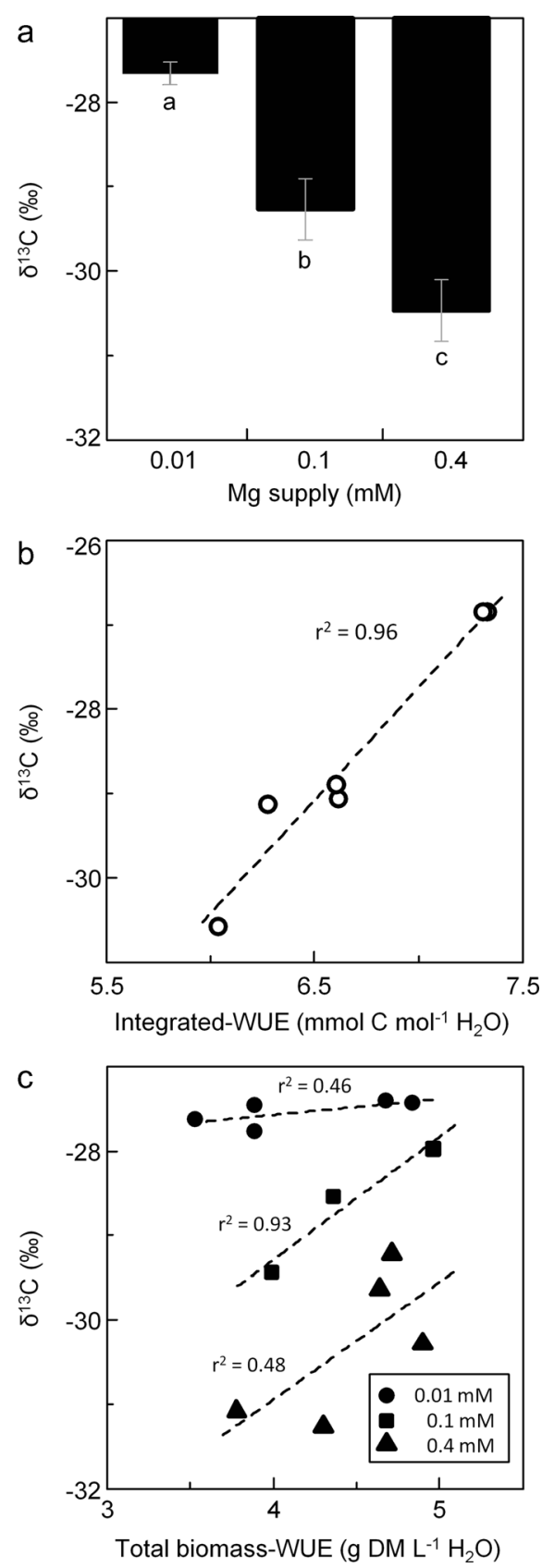

Fig. $6 \delta^{13} \mathrm{C}$ values of shoot (a), relationship between $\delta^{13} \mathrm{C}$ of young leaves and integrated leaf water-use efficiency (leaf-WUE) (b), relationship between $\delta^{13} \mathrm{C}$ of shoot and total biomass wateruse efficiency (total biomass-WUE) (c) in low $\mathrm{Mg}(0.01 \mathrm{mM} \mathrm{Mg})$, medium $\mathrm{Mg}(0.1 \mathrm{mM} \mathrm{Mg})$, and high $\mathrm{Mg}(0.4 \mathrm{mM} \mathrm{Mg})$ treatments of barley plants. DAO = days after onset of treatment. Error bars represent standard errors $(n=3)$. Means labelled with the same small letter are not significantly different $(\alpha=0.05)$

individual linear relationships were found between shoot $\delta^{13} \mathrm{C}$ and total biomass-WUE within plants of the same $\mathrm{Mg}$ treatment.

\section{Discussion}

Effect of Mg supply on chlorophyll content and dry matter formation

Being involved in many physiological and biochemical processes, $\mathrm{Mg}$ is an essential element for plant growth and development (Cakmak and Kirkby 2008; Cakmak and Yazici 2010; Cakmak 2013). As expected, plant total dry matter (DM) formation responded significantly to the various $\mathrm{Mg}$ supply regimes (Table 1). In a similar study on wheat, authors reported a decrease of $21 \%$ in total DM within $23 \mathrm{DAO}$ when concentration of supplied $\mathrm{Mg}$ decreased from 0.45 to $0.015 \mathrm{mM}$ (Mengutay et al. 2013). Magnesium leaf concentrations were lower in older leaves than in younger leaves, an effect that is well known to be attributable to the phloem-mobile nature of $\mathrm{Mg}$ within the plant: $\mathrm{Mg}$ is thought to be relocated from the older to the younger leaves enabling the plant to start the generative phase in order to finish its life cycle. One of the major functions of $\mathrm{Mg}$ in plants is its role as the central atom of the chlorophyll molecule in the light absorbing complex of chloroplasts and its contribution to the photosynthetic carbon dioxide fixation (Cakmak and Kirkby 2008). In the present study, chlorophyll content of Mg-deficient plants was remarkably lower than in adequate Mg-supplied plants. Visual leaf symptoms of $\mathrm{Mg}$ deficiency appeared as interveinal leaf chlorosis being apparent first on older leaves. The latter progressed to the young leaves as the deficiency became more severe over time, which might be attributable to the phloem-mobile behavior of Mg (Hermans et al. 2013). Chlorosis and following necrosis might be, among other reasons, a consequence of increased ROS generation, such as hydrogen peroxide $\left(\mathrm{H}_{2} \mathrm{O}_{2}\right)$. Increased levels of $\mathrm{H}_{2} \mathrm{O}_{2}$ under $\mathrm{Mg}$ deficiency might be attributed to a lower demand for reductants in the Calvin cycle and concomitant fully reduced photosynthetic electron carriers which results in an increased electron flow to $\mathrm{O}_{2}$. The reduced oxygen is then dismutated to $\mathrm{H}_{2} \mathrm{O}_{2}$. In line with our data, higher $\mathrm{H}_{2} \mathrm{O}_{2}$ concentrations in $\mathrm{Mg}$ deficient maize leaves (Tewari et al. 2004) and mulberry plants (Tewari et al. 2006) were reported. An increased activity of key ROS scavenging enzymes (APX, SOD and GR) indicates an activation of the antioxidant machinery and an increased effort to reduce, viz. detoxify $\mathrm{H}_{2} \mathrm{O}_{2}$ in the chloroplasts. In line with the present study, enhanced activities of ROS scavenging enzymes under $\mathrm{Mg}$ deficiency were observed in maize 
(Tewari et al. 2004), wheat (Mengutay et al. 2013), citrus (Tang et al. 2012; Yang et al. 2012) and bean (Cakmak 1994). The fact that $\mathrm{H}_{2} \mathrm{O}_{2}$ concentrations in $\mathrm{Mg}_{\text {low }}$ were higher than in $\mathrm{Mg}_{\text {med }}$ and $\mathrm{Mg}_{\text {high }}$ despite highest APX and GR activities indicates that the capacity of $\mathrm{H}_{2} \mathrm{O}_{2}$ scavenging was insufficient and thus, the generation of $\mathrm{H}_{2} \mathrm{O}_{2}$ might be one of the stress factors that contribute to growth reductions under severe $\mathrm{Mg}$ deficiency.

In the present experiment, the shoot/root ratio was similar in all treatments indicating no significant effect of Mg supply on DM allocation (Table 1). A number of reports showed an increased shoot/root ratio under $\mathrm{Mg}$ deficiency, for example in wheat and maize (Mengutay et al. 2013), bean (Cakmak et al. 1994b) and coffee (Meireles da Silva et al. 2014). Such increase in shoot/ root ratio is commonly attributed to the negative effect of $\mathrm{Mg}$ deficiency on phloem loading and assimilate translocation. In contrast, in studies on Arabidopsis (Hermans and Verbruggen 2005) and sugar beet (Hermans et al. 2005) the shoot/root ratio did not change. So far, we do not have a clear explanation for this discrepancy; however, it may be related to the duration of the $\mathrm{Mg}$ deficiency and the vegetation period in our experiment. Verbruggen and Hermans (2013) suggested a more severe impact on root growth than on shoot growth, hence an increase in shoot/root ratio can only be observed when young plants are exposed to $\mathrm{Mg}$ deficiency. We may speculate that when plants are grown with sufficient $\mathrm{Mg}$ concentrations before exposing them to $\mathrm{Mg}$ deficiency, like in our study, no or less pronounced changes may occur. Currently, knowledge on the effect of Mg-deficiency on root developement is still scarce, thus further research in this area is needed.

Leaf gas exchange and leaf water-use efficiency affected by Mg supply

In the present study, low Mg supply decreased both mean $A_{N}$ and $g_{s}$ significantly. Similarly, Terry and Ulrich (1974) reported a rapid decline in $A_{N}$ due to $\mathrm{Mg}$ deficiency in sugar beet already 7 DAO. Similar results were obtained in studies on Pinus (Laing et al. 2000; Sun et al. 2001), citrus (Tang et al. 2012; Yang et al. 2012), sugar beet (Terry and Ulrich 1974) and maize (Jezek et al. 2015). Tang et al. (2012) proposed nonstomatal reasons for a decrease in $\mathrm{A}_{\mathrm{N}}$ in citrus, as the internal $\mathrm{CO}_{2}$ concentration did not differ from that of plants supplied with adequate amounts of $\mathrm{Mg}$. Significant decreases of $\mathrm{A}_{\mathrm{N}}$ in $\mathrm{Mg}_{\text {low }}$ indicate that $\mathrm{Mg}$ deprivation did not only decrease the rate of leaf area expansion but also photosynthetic carbon gain per unit leaf area. This decrease in photosynthetic efficiency, which was most prominent in the $\mathrm{Mg}_{\text {low }}$-treated plants, might also explain why excessive $\mathrm{H}_{2} \mathrm{O}_{2}$ formation was highest in the $\mathrm{Mg}_{\text {low }}$ treatment: it is very likely that an incomplete or blocked photosynthesis causally triggered the formation of oxygen radicals due to higher light intensities than sufficient to saturate photosynthetic processes under the experimental conditions. Mg deficiency induced decreases in $A_{N}$ are commonly attributed to i) a decrease in chlorophyll content (Peaslee and Moss 1966), and ii) an accumulation of carbohydrates in leaves suffering $\mathrm{Mg}$ deficiency causing feedback inhibition of RubisCo activity, and higher mesophyll resistance towards $\mathrm{CO}_{2}$ diffusion (Terry and Ulrich 1974). Furthermore, $\mathrm{Mg}$ deficiency leads to changes in the ultrastructure of chloroplasts as thylakoid stacks are disrupted (Hall et al. 1972). Ceppi et al. (2012) observed a decrease in maximum fluorescence intensity $\left(F_{M}\right)$ during measurement of fast chlorophyll flourescence induction kinetics on sugar beet. The authors attributed the decrease of $F_{M}$ to the disruption of grana stacks and an increasing spillover of energy from photosystem (PS) II to PS I (Ceppi et al. 2012). Grana disruption diminishes the segregation of PSI and PSII (Stys 1995) and leads to quenching of PSII fluorescence (Murata 1969). This and the above mentioned reasons might explain the detrimental effects of $\mathrm{Mg}$ deficiency on photosynthesis.

Tang et al. (2012) and Yang et al. (2012) reported lower $\mathrm{g}_{\mathrm{s}}$ in $\mathrm{Mg}$ deficient Citrus plants. A decrease of $g_{s}$ was also reported by Kobayashi et al. (2013). In their study on rice plants, Mg deficiency had a more pronounced effect on transpiration rates, as the latter declined earlier than assimilation rates. Similarly in our study, the stomatal conductance was distinctly affected, as the decrease in $g_{s}$ in $\mathrm{Mg}_{\text {low }}$ compared to $\mathrm{Mg}_{\text {high }}$ was more pronounced than the decrease in $\mathrm{A}_{\mathrm{N}}$, causing higher leaf-WUE. To our knowledge, there are no studies that analyze effects of varying $\mathrm{Mg}$ supply on leaf-WUE. For the first time, the presented data clearly indicate that severe $\mathrm{Mg}$ deficiency enhances leaf-WUE. Certainly, more details on the genetic nature of this relationship are needed to understand whether this is a common relationship or whether it is specific for barley. 
Effect of Mg supply on biomass water-use efficiency

At the whole-plant level, WUE is defined as plant dry matter production per unit of water loss by transpiration (biomass-WUE). As in the calculation of shoot biomassWUE root biomass production is not considered, shoot biomass-WUE is lower than total biomass-WUE in all three treatments, but significant differences remain comparing $\mathrm{Mg}_{\text {low }}$ and $\mathrm{Mg}_{\text {high. }}$. This trend is as expected since the shoot/root ratio did not change significantly with differing $\mathrm{Mg}$ levels. In the present study, there were no significant differences in either shoot- or total biomass-WUE measured on $34 \mathrm{DAO}$ when comparing $\mathrm{Mg}_{\text {med }}$ and $\mathrm{Mg}_{\text {high }}$, although biomass was about $34 \%$ lower (34 DAO), but severe $\mathrm{Mg}$ deficiency decreased shoot- and total biomass-WUE by about $20 \%$ on 34 DAO. It is commonly accepted that biomass-WUE increases under elevated nitrogen (Ripullone et al. 2004; Brueck and Senbayram 2009) and potassium supply (Römheld and Kirkby 2010; Grzebisz et al. 2013), but to our knowledge until today, there are no studies reporting on effects of $\mathrm{Mg}$ nutrition on biomass-WUE. Yield depression of barley in $\mathrm{Mg}_{\text {med }}$ was significant (34 \%) when compared to $\mathrm{Mg}_{\text {high }}$; however, biomassWUE was similar in both treatments. This clearly suggests that only severe $\mathrm{Mg}$ deficiency affects biomassWUE.

Surprisingly, shoot- and total biomass-WUE and leaf-WUE were showing opposite trends: shoot- and total biomass-WUE decreased under Mg deficiency whereas leaf-WUE showed an increase under Mg deficiency. Discrepancies between whole plant-WUE and leaf-WUE were also reported by Tomás et al. (2012) and Senbayram et al. (2015b). In their studies on grapevine cultivars and tobacco, the large variability in whole plant-WUE was not reflected in leaf-WUE as determined by gas exchange and $\delta^{13} \mathrm{C}$. This discrepancy might be due to the complexity of factors which are involved in regulating biomass-WUE, but are not directly addressed when measuring instantaneous leaf gas exchange. Compared to leaf-WUE, biomass-WUE takes into account carbon loss (e.g., respiration, root exudates) and unproductive water loss (from nonphotosynthesizing parts, and/or night-time transpiration from the leaves), which are two additional parameters that might substantially contribute to the variation in biomass-WUE. One may speculate that higher nighttime respiration specifically from the leaves (due to high soluble sugar content) or excessive rates of root exudation in severely $\mathrm{Mg}$ deficient plants may contribute to the decline in biomass-WUE. Root exudation may release remarkable amounts of fixed carbon into the rhizosphere; meaning a pronounced loss of reduced carbon assuming that most of the exudates are not reabsorbed by retrieval mechanisms (Kuzyakov and $\mathrm{Xu}$ 2013). Usually, retrieval of exuded carbonic compounds such as sugars is partly driven by an $\mathrm{H}^{+}$electrochemical gradient which is established by $\mathrm{H}^{+}$-ATPase activity. The generated proton gradient drives the uptake of sugars by means of $\mathrm{H}^{+}$/sugar-cotransporter (Jones et al. 2009). Enhanced net release of sugars was found when plasma membrane ATPase was inhibited and consequently, the proton gradient degraded (Mühling et al. 1993). As the activity of $\mathrm{H}^{+}$-ATPase is strongly dependent on the presence of $\mathrm{Mg}^{2+}$ ions (Palmgren 2001), the retrieval mechanism might be disturbed under Mg deficiency. Enhanced root exudation due to mineral deficiency such as potassium deficiency (Kraffczyk et al. 1984), iron-, phosphorous- or nitrogen deficiency was observed in maize (Carvalhais et al. 2011).

Increased dark respiration under progressing Mg deficiency was reported in sugar beet (Terry and Ulrich 1974), and in Phaseolus vulgaris (Fischer and Bremer 1993). In the latter study, dark respiration rates of $\mathrm{Mg}$ deficient plants were $50 \%$ higher than in control plants 6 days after onset of $\mathrm{Mg}$ deficiency. In conclusion, the decrease in biomass-WUE under severe $\mathrm{Mg}$ deficiency may be attributed to possible excessive carbon loss from the root (as exudates) and/or from leaves (night-time respiration).

Shoot- and total biomass-WUE can only give insight into the time-integrated responses at one specific time-point, but not into any dynamics. Thus, in order to understand the dynamics of progressing $\mathrm{Mg}$ deficiency and biomass-WUE, we studied variation in daily shoot-WUE throughout the vegetation period via empirical modeling. The strong decrease of daily shoot-WUE in $\mathrm{Mg}$ deficient plants after 18 DAO might be partly attributable to the decline in biomass production as the latter occurred as well after 18 DAO (see Online Resource 2). Furthermore, unproductive water loss at night was significantly higher in $\mathrm{Mg}$ deficient plants (data not shown), which is another factor that may cause lower biomass-WUE under $\mathrm{Mg}$ deficiency. In our study, night-time water loss in $\mathrm{Mg}$ deficient plants reached $35 \%$ of daytime transpiration. Night-time transpiration rates may vary 
between 5 and $15 \%$ of daytime transpiration and, in some cases, rates of up to $30 \%$ were reported (Benyon 1999; Snyder et al. 2003). Night-time transpiration without simultaneous carbon gain imposes carbon costs to the plant; however, it might be beneficial by increasing transpiration-driven mass flow to the root rhizosphere, thus enhancing nutrient availability during night, which positively affects plant productivity and growth (Caird et al. 2007). Here, higher night-time transpiration without concomitant biomass production might partly contribute to reduced biomass-WUE.

\section{Effect of Mg supply on carbon isotope composition}

Carbon isotope discrimination reflects the timeintegrated $\mathrm{CO}_{2}$ partial pressure at the carboxylation site $\left(c_{c}\right)$ and therefore can be used to calculate time integrated $\mathrm{c}_{\mathrm{c}} / \mathrm{c}_{\mathrm{a}}$ ratios which are sensitive to $\mathrm{A}, \mathrm{g}_{\mathrm{s}}$ and mesophyll conductance (Seibt et al. 2008; Buckley and Warren 2014). Overall, shoot $\delta^{13} \mathrm{C}$ values decreased with increasing $\mathrm{Mg}$ supply indicating a change in the $\mathrm{c}_{\mathrm{c}} / \mathrm{c}_{\mathrm{a}}$ ratio possibly due to the restriction in $\mathrm{CO}_{2}$ diffusion by either stomatal $\left(\mathrm{g}_{\mathrm{s}}\right)$ or mesophyll $\left(\mathrm{g}_{\mathrm{m}}\right)$ conductance. The significant positive relationship between $\delta^{13} \mathrm{C}$ values of young leaves and leaf-WUE (Fig. 6b) is in accordance with the linear model introduced by Farquhar et al. (1982), where $\delta^{13} \mathrm{C}$ represents a temporal integration of leaf-WUE and where variability in $\mathrm{CO}_{2}$-diffusion is determined by $\mathrm{c}_{\mathrm{i}} / \mathrm{c}_{\mathrm{a}}$, the ratio of leaf internal to atmospheric concentration, alone. As seen in Fig. 6b, about $96 \%$ of the variation in $\delta^{13} \mathrm{C}$ values is explained by the change in leaf-WUE. Thus, we may speculate that in our study $\mathrm{g}_{\mathrm{m}}$ was not significantly affected by varying $\mathrm{Mg}$ supply, although changes of leaf density by e.g. increased concentrations of non-structural carbohydrates, which are commonly associated with $\mathrm{Mg}$ deficiency (Cakmak et al. 1994a), can cause a reduction of $g_{m}$ (Flexas et al. 2012). Surprisingly, a common relationship could not be established between average shoot $\delta^{13} \mathrm{C}$ and total biomass-WUE. However, significant individual linear relationships were found between shoot $\delta^{13} \mathrm{C}$ and total biomass-WUE when plotting each $\mathrm{Mg}$ treatment separately. The linear response of average shoot $\delta^{13} \mathrm{C}$ to total biomass-WUE differed in slope and intercept with respect to $\mathrm{Mg}$ supply.

Both $\delta^{13} \mathrm{C}$ and leaf-WUE data clearly showed that the decrease in biomass-WUE in $\mathrm{Mg}_{\text {low }}$ treatment was not solely due to the variation in photosynthesis or photosynthesis-related $g_{s}$. Therefore, we conclude that lower biomass-WUE in $\mathrm{Mg}_{\text {low }}$ treatment might be attributable to the increase in nocturnal stomatal conductance, respiration or excessive root exudation as discussed above. Thus, this study is the first to establish a direct positive effect of $\mathrm{Mg}$ supply on biomass-WUE.

\section{Conclusion}

The aim of the current study was to improve our understanding on the direct effect of Mg supply on biomassWUE and related parameters, e.g. leaf-WUE, and carbon isotope discrimination under non-limiting water supply. In this context, we draw the following conclusions:

- $\mathrm{H}_{2} \mathrm{O}_{2}$ concentrations were increased in $\mathrm{Mg}_{\text {low }}$ plants, although the activities of the ROS scavenging enzymes APX, GR and SOD were highest in in this experimental treatment. Plants that suffered from moderate $\mathrm{Mg}$-deficiency maintained $\mathrm{H}_{2} \mathrm{O}_{2}$ on the level of plants treated with adequate amounts of $\mathrm{Mg}$. Thus we conclude that the capacity of the antioxidative machinery to detoxify ROS is exhausted only under conditions of severe $\mathrm{Mg}$ deficiency.

- Leaf-WUE and $\delta^{13} \mathrm{C}$ values (showing time integrated leaf-WUE) were higher under $\mathrm{Mg}$ deficiency.

- In contrast to leaf-WUE, our experiment clearly showed that shoot- and total biomass-WUE decreased under severe Mg deficiency. Mild Mg deficiency caused a significant decrease in DM production (34\%), but did not affect biomass-WUE. We speculate that a possible variation in nocturnal stomatal conductance, night respiration and/or excessive root exudates may be responsible for the decrease in biomass-WUE under severe $\mathrm{Mg}$ deficiency.

Open Access This article is distributed under the terms of the Creative Commons Attribution 4.0 International License (http:// creativecommons.org/licenses/by/4.0/), which permits unrestricted use, distribution, and reproduction in any medium, provided you give appropriate credit to the original author(s) and the source, provide a link to the Creative Commons license, and indicate if changes were made. 


\section{References}

Arquero O, Barranco D, Benlloch M (2006) Potassium starvation increases stomatal conductance in olive trees. Hortscience 41:433-436

Asada K (1999) The water-water cycle in chloroplasts: scavenging of active oxygens and dissipation of excess photons. Annu Rev Plant Physiol Plant Mol Biol 50:601-639. doi:10.1146/ annurev.arplant.50.1.601

Benyon R (1999) Nighttime water use in an irrigated Eucalyptus grandis plantation. Tree Physiol 19:853-859. doi:10.1093/ treephys/19.13.853

Blum A (2009) Effective use of water (EUW) and not water-use efficiency (WUE) is the target of crop yield improvement under drought stress. F Crop Res 112:119-123. doi:10.1016/ j.fcr.2009.03.009

Bramley H, Turner NC, Siddique KHM (2013) Water use efficiency. In: Kole C (ed) Genomics and breeding for climate resilient crops, vol 2. Springer Science \& Business Media, New York, pp. 225-269

Brueck H, Senbayram M (2009) Low nitrogen supply decreases water-use efficiency of oriental tobacco. J Plant Nutr Soil Sci 172:216-223. doi:10.1002/jpln.200800097

Buckley TN, Warren CR (2014) The role of mesophyll conductance in the economics of nitrogen and water use in photosynthesis. Photosynth Res 119:77-88. doi:10.1007/s11120013-9825-2

Caird MA, Richards JH, Donovan LA (2007) Nighttime stomatal conductance and transpiration in $\mathrm{C} 3$ and $\mathrm{C} 4$ plants. Plant Physiol 143:4-10. doi:10.1104/pp.106.092940

Cakmak I (2013) Magnesium in crop production, food quality and human health. Plant Soil 368:1-4. doi:10.1007/s11104-0131781-2

Cakmak I (1994) Activity of ascorbate-dependent $\mathrm{H}_{2} \mathrm{O}_{2}$-scavenging enzymes and leaf chlorosis are enhanced in magnesiumand potassium-deficient leaves, but not in phosphorusdeficient leaves. J Exp Bot 45:1259-1266

Cakmak I, Hengeler C, Marschner H (1994a) Changes in phloem export of sucrose in leaves in response to phosphorus, potassium and magnesium deficiency in bean plants. J Exp Bot 45: 1251-1257. doi:10.1093/jxb/45.9.1251

Cakmak I, Hengeler C, Marschner H (1994b) Partitioning of shoot and root dry matter and carbohydrates in bean plants suffering from phosphorus, potassium and magnesium deficiency. J Exp Bot 45:1245-1250. doi:10.1093/jxb/45.9.1245

Cakmak I, Kirkby EA (2008) Role of magnesium in carbon partitioning and alleviating photooxidative damage. Physiol Plant 133:692-704. doi:10.1111/j.1399-3054.2007.01042.x

Cakmak I, Marschner H (1992) Magnesium deficiency and high light intensity enhance activities of superoxide dismutase, ascorbate peroxidase, and glutathione reductase in bean leaves. Plant Physiol 98:1222-1227. doi:10.1104/pp.98.4. 1222

Cakmak I, Yazici AM (2010) Magnesium: a forgotten element in crop production. Better Crop 94:23-25

Carvalhais LC, Dennis PG, Fedoseyenko D, et al. (2011) Root exudation of sugars, amino acids, and organic acids by maize as affected by nitrogen, phosphorus, potassium, and iron deficiency. J Plant Nutr Soil Sci 174:3-11. doi:10.1002/ jpln.201000085
Ceppi MG, Oukarroum A, Çiçek N, et al. (2012) The IP amplitude of the fluorescence rise OJIP is sensitive to changes in the photosystem I content of leaves: a study on plants exposed to magnesium and sulfate deficiencies, drought stress and salt stress. Physiol Plant 144:277-288. doi:10.1111/j.1399-3054. 2011.01549.x

Cernusak LA, Tcherkez G, Keitel C, et al. (2009) Viewpoint: why are non-photosynthetic tissues generally ${ }^{13} \mathrm{C}$ enriched compared with leaves in $\mathrm{C}_{3}$ plants? Review and synthesis of current hypotheses. Funct Plant Biol 36:199-213

Cheeseman JM (2007) Hydrogen peroxide and plant stress : a challenging relationship. Plant Stress 1:4-15

Cheeseman JM (2009) Seasonal patterns of leaf $\mathrm{H}_{2} \mathrm{O}_{2}$ content: reflections of leaf phenology, or environmental stress? Funct Plant Biol 36:721-731. doi:10.1071/FP09014

Claussen W (2002) Growth, water use efficiency, and proline content of hydroponically grown tomato plants as affected by nitrogen source and nutrient concentration. Plant Soil 247: 199-209

Ding Y, Luo W, Xu G (2006) Characterisation of magnesium nutrition and interaction of magnesium and potassium in rice. Ann Appl Biol 149:111-123. doi:10.1111/j.1744-7348.2006. 00080.x

Farooq M, Wahid A, Basra NKDFSMA (2009) Plant drought stress: effects, mechanisms and management. Agronomy for Sustainable Development. Springer Verlag, In, pp. 185212

Farquhar GD, MH O'L, JA B (1982) On the relationship between carbon isotope discrimination and the intercellular carbon dioxide concentration in leaves. Aust J Plant Physiol 9: 121-137

Farquhar GD, Richards RA (1984) Isotopic composition of plant carbon correlates with water-use efficiency of wheat genotypes. Aust J Plant Physiol 11:539-552

Fischer ES, Bremer E (1993) Influence of magnesium deficiency on rates of leaf expansion, starch and sucrose accumulation, and net assimilation in Phaseolus vulgaris. Physiol Plant 89: 271-276

Flexas J, Barbour MM, Brendel O, et al. (2012) Mesophyll diffusion conductance to $\mathrm{CO}_{2}$ : an unappreciated central player in photosynthesis. Plant Sci 193-194:70-84. doi:10.1016/j. plantsci.2012.05.009

Fournier JM, Roldán ÁM, Sánchez C, et al. (2005) K ${ }^{+}$starvation increases water uptake in whole sunflower plants. Plant Sci 168:823-829. doi:10.1016/j.plantsci.2004.10.015

Foyer CH, Noctor G (2011) Ascorbate and glutathione: the heart of the redox hub. Plant Physiol 155:2-18. doi:10.1104/pp. 110.167569

Foyer CH, Shigeoka S (2011) Understanding oxidative stress and antioxidant functions to enhance photosynthesis. Plant Physiol 155:93-100. doi:10.1104/pp.110.166181

Giannopolitis CN, Ries SK (1977) Superoxide dismutases: occurrence in higher plants. Plant Physiol 59:309-314. doi:10. 1146/annurev.bi.44.070175.001051

Grzebisz W, Gransee A, Szczepaniak W, Diatta J (2013) The effects of potassium fertilization on water-use efficiency in crop plants. J Plant Nutr Soil Sci 176:355-374. doi:10.1002/ jpln.201200287

Hall JD, Barr R, Al-Abbas AH, Crane FL (1972) The ultrastructure of chloroplasts in mineral-deficient maize leaves. Plant Physiol 50:404-409. doi:10.1104/pp.50.3.404 
Halliwell B, Foyer CH (1978) Properties and physiological function of a glutathione reductase purified from spinach leaves by affinity chromatography. Planta 139:9-17. doi:10.1007/ BF00390803

Hermans C, Bourgis F, Faucher M, et al. (2005) Magnesium deficiency in sugar beets alters sugar partitioning and phloem loading in young mature leaves. Planta 220:541-549. doi:10. 1007/s00425-004-1376-5

Hermans C, Conn SJ, Chen J, et al. (2013) An update on magnesium homeostasis mechanisms in plants. Met Integr biometal Sci 5:1170-1183. doi:10.1039/c3mt20223b

Hermans C, Johnson GN, Strasser RJ, Verbruggen N (2004) Physiological characterisation of magnesium deficiency in sugar beet: acclimation to low magnesium differentially affects photosystems I and II. Planta 220:344-355. doi:10. 1007/s00425-004-1340-4

Hermans C, Verbruggen N (2005) Physiological characterization of $\mathrm{Mg}$ deficiency in Arabidopsis thaliana. J Exp Bot 56: 2153-2161. doi:10.1093/jxb/eri215

Hu X, Zhang A, Zhang J, Jiang M (2006) Abscisic acid is a key inducer of hydrogen peroxide production in leaves of maize plants exposed to water stress. Plant Cell Physiol 47:14841495. doi:10.1093/pcp/pcl014

Jang JC, Sheen J (1994) Sugar sensing in higher-plants. Plant Cell 6:1665-1679. doi:10.1105/tpc.6.11.1665

Jezek M, Geilfus C-M, Bayer A, Mühling K-H (2015) Photosynthetic capacity, nutrient status, and growth of maize (Zea mays L.) upon $\mathrm{MgSO}_{4}$ leaf-application. Front Plant Sci 5:1-10. doi:10.3389/fpls.2014.00781

Jones DL, Nguyen C, Finlay RD (2009) Carbon flow in the rhizosphere: carbon trading at the soil-root interface. Plant Soil 321:5-33. doi:10.1007/s11104-009-9925-0

Kobayashi NI, Saito T, Iwata N, et al. (2013) Leaf senescence in rice due to magnesium deficiency mediated defect in transpiration rate before sugar accumulation and chlorosis. Physiol Plant 148:490-501. doi:10.1111/ppl.12003

Kraffczyk I, Trolldenier G, Beringer H (1984) Soluble root exudates of maize: influence of potassium supply and rhizosphere microorganisms. Soil Biol Biochem 16:315-322

Kuzyakov Y, Xu X (2013) Competition between roots and microorganisms for nitrogen: mechanisms and ecological relevance. New Phytol 198:656-669. doi:10.1111/nph.12235

Laing W, Greer D, Sun O, et al. (2000) Physiological impacts of $\mathrm{Mg}$ deficiency in Pinus radiata: growth and photosynthesis. New Phytol 146:47-57. doi:10.1046/j.1469-8137.2000. 00616.x

Lewis JD, Phillips NG, Logan BA, et al. (2011) Leaf photosynthesis, respiration and stomatal conductance in six Eucalyptus species native to mesic and xeric environments growing in a common garden. Tree Physiol 31:997-1006. doi:10.1093/treephys/tpr087

Li L, Tutone AF, Drummond RSM, et al. (2001) A novel family of magnesium transport genes in Arabidopsis. Plant Cell 13: 2761-2775. doi:10.1105/tpc.010352

Medrano H, Tomás M, Martorell S, et al. (2015) From leaf to whole-plant water use efficiency (WUE) in complex canopies: limitations of leaf WUE as a selection target. Crop J 3: 220-228. doi:10.1016/j.cj.2015.04.002

Meireles da Silva D, Brandão IR, Alves JD, et al. (2014) Physiological and biochemical impacts of magnesium- deficiency in two cultivars of coffee. Plant Soil 382:133150. doi:10.1007/s11104-014-2150-5

Mengutay M, Ceylan Y, Kutman UB, Cakmak I (2013) Adequate magnesium nutrition mitigates adverse effects of heat stress on maize and wheat. Plant Soil 368:57-72. doi:10.1007/ s11104-013-1761-6

Møller IM, Jensen PE, Hansson A (2007) Oxidative modifications to cellular components in plants. Annu Rev Plant Biol 58: 459-481. doi:10.1146/annurev.arplant.58.032806.103946

Mühling KH, Schubert S, Mengel K (1993) Role of plasmalemma $\mathrm{H}+$ ATPase in sugar retention by roots of intact maize and field bean plants. Z Pflanzenernähr Bodenkd 156:155-161

Murata N (1969) Control of excitation transfer in photosynthesis. II. Magnesium ion dependent distribution of excitation energy between two pigment systems in spinach chloroplasts. Biochim Biophys Acta 189:171-181

Nakano Y, Asada K (1981) Hydrogen peroxide is scavenged by ascorbat-specific peroxidase in spinach chloroplasts. Plant Cell Physiol 22:867-880

Palmgren MG (2001) Plant plasma membrane H+ - ATPases: powerhouses for nutrient uptake. Annu Rev Plant Physiol Plant Mol Biol 52:817-845. doi:10.1146/annurev.arplant.52. 1.817

Peaslee D, Moss N (1966) Photosynthesis in K- and Mg-deficient maize leaves. Soil Sci Soc Am Proc 30:220-223

Polle A (2001) Dissecting the superoxide dismutase-ascorbateglutathione-pathway in chloroplasts by metabolic modeling. Computer simulations as a step towards flux analysis. Plant Physiol 126:445-462. doi:10.1104/pp.126.1.445

Core Team R (2014) R: a language and environment for statistical computing. R Foundation for Statistical Computing, Vienna, Austria

Pachauri RK, Meyer LA (2014) Climate change 2014: synthesis report. Contribution of Working Groups I, II and III to the Fifth Assessment Report of the Intergovernmental Panel on Climate Change

Rasband WS (1997) ImageJ. U. S, National Institutes of Health, Bethesda, Maryland, USA

Rasheed F, Dreyer E, Richard B, et al. (2013) Genotype differences in ${ }^{13} \mathrm{C}$ discrimination between atmosphere and leaf matter match differences in transpiration efficiency at leaf and whole-plant levels in hybrid Populus deltoides $\times$ nigra. Plant Cell Environ 36:87-102

Ripullone F, Lauteri M, Grassi G, et al. (2004) Variation in nitrogen supply changes water-use efficiency of Pseudotsuga menziesii and Populus $x$ euroamericana; a comparison of three approaches to determine water-use efficiency. Tree Physiol 24:671-679. doi:10.1093/treephys/24.6.671

Römheld V, Kirkby EA (2010) Research on potassium in agriculture: needs and prospects. Plant Soil 335:155-180. doi:10. 1007/s11104-010-0520-1

Seibt U, Rajabi A, Griffiths H, Berry JA (2008) Carbon isotopes and water use efficiency: sense and sensitivity. Oecologia 155:441-454. doi:10.1007/s00442-007-0932-7

Senbayram M, Gransee A, Wahle V, Thiel H (2015a) Role of magnesium fertilisers in agriculture: plant - soil continuum. Crop Pasture Sci 66:1219-1229

Senbayram M, Tränkner M, Dittert K (2015b) Brück H. Daytime leaf water use efficiency does not explain the relationship between plant $\mathrm{N}$ status and biomass water-use efficiency of tobacco under non-limiting water supply 178:682-692 
Shangguan ZP, Shao MA, Dyckmans J (2000) Nitrogen nutrition and water stress effects on leaf photosynthetic gas exchange and water use efficiency in winter wheat. Environ Exp Bot 44:141-149. doi:10.1016/S0098-8472(00)00064-2

Shaul O (2002) Magnesium transport and function in plants: the tip of the iceberg. Biometals 15:309-323. doi:10.1023/ a:1016091118585

Smith BN, Epstein S (1971) Two categories of ${ }^{13} \mathrm{C} /{ }^{12} \mathrm{C}$ ratios for higher plants. Plant Physiol 47:380-384

Snyder KA, Richards JH, Donovan LA (2003) Night-time conductance in $\mathrm{C} 3$ and $\mathrm{C} 4$ species: do plants lose water at night? J Exp Bot 54:861-865. doi:10.1093/jxb/erg082

Soolanayakanahally RY, Guy RD, Silim SN, et al. (2009) Enhanced assimilation rate and water use efficiency with latitude through increased photosynthetic capacity and internal conductance in balsam poplar (Populus balsamifera L.). Plant Cell Environ 32:1821-1832

Stys D (1995) Stacking and separation of photosystem I and photosystem II in plant thylakoid membranes: a physicochemical view. Physiol Plant 95:651-657. doi:10.1034/j. 1399-3054.1995.950421.x

Sun OJ, Gielen GJ, Sands R, et al. (2001) Growth, Mg nutrition and photosynthetic activity in Pinus radiata: evidence that $\mathrm{NaCl}$ addition counteracts the impact of low Mg supply. Trees Struct Funct 15:335-340. doi:10.1007/s004680100111

Tallec T, Béziat P, Jarosz N, et al. (2013) Crops' water use efficiencies in temperate climate: comparison of stand, ecosystem and agronomical approaches. Agric For Meteorol 168:69-81. doi:10.1016/j.agrformet.2012.07.008

Tang N, Li Y, Chen LS (2012) Magnesium deficiency-induced impairment of photosynthesis in leaves of fruiting Citrus reticulata trees accompanied by up-regulation of antioxidant metabolism to avoid photo-oxidative damage. J Plant Nutr Soil Sci 175:784-793. doi:10.1002/jpln.201100329

Terry N, Ulrich A (1974) Effects of magnesium deficiency on the photosynthesis and respiration of leaves of sugar beet. Plant Physiol 54:379-381. doi:10.1104/pp.54.3.379

Tewari RK, Kumar P, Nand Sharma P (2006) Magnesium deficiency induced oxidative stress and antioxidant responses in mulberry plants. Sci Hortic (Amsterdam) 108:7-14. doi:10. 1016/j.scienta.2005.12.006

Tewari RK, Kumar P, Tewari N, et al. (2004) Macronutrient deficiencies and differential antioxidant responses - influence on the activity and expression of superoxide dismutase in maize. Plant Sci 166:687-694. doi:10.1016/j.plantsci.2003. 11.004

Tomás M, Medrano H, Pou a., et al (2012) Water-use efficiency in grapevine cultivars grown under controlled conditions: effects of water stress at the leaf and whole-plant level. Aust J Grape Wine Res 18:164-172. doi:10.1111/j.1755-0238. 2012.00184.x

Verbruggen N, Hermans C (2013) Physiological and molecular responses to magnesium nutritional imbalance in plants. Plant Soil 368:87-99. doi:10.1007/s11104-013-1589-0

Wang P, Song CP (2008) Guard-cell signalling for hydrogen peroxide and abscisic acid. New Phytol 178:703-718. doi: 10.1111/j.1469-8137.2008.02431.x

Wang Y, Zhang X, Liu X, et al. (2013) The effects of nitrogen supply and water regime on instantaneous WUE, timeintegrated WUE and carbon isotope discrimination in winter wheat. F Crop Res 144:236-244

Warren CR, Adams MA (2006) Internal conductance does not scale with photosynthetic capacity: implications for carbon isotope discrimination and the economics of water and nitrogen use in photosynthesis. Plant Cell Environ 29:192-201

Wilkinson SR, Welch RM, Mayland HF, Grunes DL (1990) Magnesium in plants: uptake, distribution, function, and utilization by man and animals. Met Ions Biol Syst 26:33-56

Wolff SP (1994) Ferrous ion oxidation in presence of ferric ion indicator xylenol orange for measurement of hydroperoxides. Methods Enzymol 233:182-189

Yang GH, Yang LT, Jiang HX, et al. (2012) Physiological impacts of magnesium-deficiency in Citrus seedlings: photosynthesis, antioxidant system and carbohydrates. Trees - Struct Funct 26:1237-1250. doi:10.1007/ s00468-012-0699-2 